\title{
ANALYSIS
}

Article received on October $5^{\text {th }} 2016$ Article accepted on December $19^{\text {th }} 2016$

UDC: $785.7: 788.1 / .4$

\author{
Jelena Janković-Beguš* \\ Belgrade Festivals Center - CEBEF
}

\section{PLAYING THE GAME WITH ALEATORICS AND NARRATIVITY: LINALA-AGON BY IANNIS XENAKIS ${ }^{1}$}

\begin{abstract}
In this article I examine the piece Linaia-Agon for brass trio (1972) by GreekFrench composer Iannis Xenakis, one of only three pieces by this composer, which are commonly referred to in literature as "game-pieces", from the perspective of Roger Caillois' typology of games, stemming from the social sciences, as well as from the framework of the mathematical game theory and its branch probability theory. Xenakis' "game pieces" belong to the field of controlled aleatorics, because they employ a certain level of indeterminacy; here I argue that it is precisely in this aspect of indeterminacy that their nature "as games" is revealed. I am concerned with the "translation" of the Ancient Greek legend about the musician Linos and the god Apollo - and of the mathematical calculations - into the language of the West European avant-garde music of the second half of the $20^{\text {th }}$ century.

Keywords: Iannis Xenakis, Linaia-Agon, "game pieces”, Roger Caillois, game theory, probability theory, aleatorics

* Author contact information: jelenaforfree@gmail.com.

${ }^{1}$ The early version of this paper was written as the final assignment for the course in "Fantasy and Ballad Principles in Music" taught by Prof. Tijana Popović Mlađenović, PhD, within the scope of doctoral academic studies in Musicology at the Faculty of Music in Belgrade (during the school year of 2015/2016). I would like to express my gratitude to Prof. Popović Mlađenović for her assistance in publishing this paper.
\end{abstract}




\section{Introduction}

The piece Linaia-Agon for brass trio (French Horn, Trombone and Tuba) ${ }^{2}$ by the Greek-French composer Iannis Xenakis (1922-2001), one of the most prominent examples of the West European musical avant-garde in the second half of the $20^{\text {th }}$ century, is one of the very few works from the composer's prolific opus which bring forth the notion of game. Namely, Xenakis composed only three pieces which are referred to in literature as "game pieces": alongside Linaia-Agon there are two earlier works for orchestra, Duel (1959) and Stratégie (1962). All three pieces belong to the field of controlled improvisation or controlled aleatorics, ${ }^{3}$ because they employ a certain level of indeterminacy. Here I argue that it is precisely in this intervention of indeterminacy that their nature "as games" is revealed.

In composing these pieces Xenakis was inspired by the game theory, which is the "study of mathematical models of conflict and cooperation between intelligent rational decision makers", ${ }^{4}$ or more precisely, by its branch called the probability theory - "translating" the mathematical calculations into the language of the West European avant-garde music of the second half of the $20^{\text {th }}$ century. The game theory started to develop after World War II as a branch of economic science, with the publication of the first edition of the book Theory of Games and Economic Behavior by the mathematician John von Neumann and

\footnotetext{
2 Published score: Salabert, 1972 (E.A.S 17.055). Xenakis composed Linaia-Agon in 1972 in Bloomington and Paris, and the piece was premiered on 26 April that same year at the Bach Festival in London. The printed score was first published in January 1973, in the French and English languages. Cf. Benny Sluchin, "Linaia-Agon: Towards an Interpretation Based on the Theory", https://www.iannis-xenakis.org/Articles/Sluchin.pdf, 4 (accessed on 13 May 2016). Benny Sluchin is an Israeli-French trombonist and mathematician, member of the Ensemble Intercontemporain and IRCAM affiliate.

${ }^{3}$ Supposedly the term aleatorics was first used by the German composer and acoustician, Werner Meyer-Eppler (Cf. Sabine Feisst, "Negotiating Freedom and Control in Composition. Improvisation and Its Offshoots 1950 to 1980", in The Oxford Handbook of Critical Improvisation Studies, Vol. 2, Edited by George E. Lewis and Benjamin Piekut, New York, Oxford University Press, 2016, 210). However, it is thanks to French composer Pierre Boulez that this term gained wider recognition: Boulez published his influential essay "Aléa" the same year in Nouvelle Revue française, $N^{\circ} 59$, 1er novembre 1957. The essay was reprinted in: Pierre Boulez, Relevés d'apprenti, Textes réunis et présentés par Paule Thévenin, Paris, Collection Tel Quel aux Éditions du Seuil, 1966; 41-55. It was published in the Serbo-Croat lanugage as: Pierre Boulez, "Alea", translated by Daša Bradičić, in Novi zvuk: izbor tekstova o suvremenoj glazbi, edited by Petar Salem, Zagreb, Nakladni zavod Matice hrvatske, 1972, 15-23.

${ }^{4}$ Cf. Myerson, Roger B., Game Theory: Analysis of Conflict, Cambridge, MA \& London, Harvard University Pess, 1991, 1.
} 
economist Oskar Morgenstern in 1944. However, according to Dušan Pavlović, the application of the game theory is considerably larger since it can be used successfully in other spheres of social activity - such as politics, international relations, and different forms of social interactions, law, religion and sport. ${ }^{5}$ Nevertheless, examples of the application of the game theory in the field of art music are quite rare; ${ }^{6}$ in his excellent analytical paper on Linaia-Agon Thomas DeLio observes that Xenakis "presents some of the first artistic applications of mathematical games"7 in his three game pieces. Xenakis is certainly - and unsurprisingly - one of the composers for whom the interaction of mathematics and music represented the core principle of creative thinking.

Iannis Xenakis' "game pieces" are examples of his particular approach to aleatoric composition in relation to the principles of stochastic music. Xenakis detailed the theoretical and practical implications of stochastic music and the application of the probability theory on musical composition in his study Musiques formelles [Formalized Music], ${ }^{8}$ using as examples his two aforementioned orchestra pieces which had been completed by that time. He returned to the same idea several years later in his piece Linaia-Agon, testing this approach for the first and last time in the chamber music genre. Bearing in mind that this piece requires the considerable intellectual engagement of its performers in "deciphering" the mathematical rules according to which the game unrolls - and in this

${ }^{5}$ Pavlović, Dušan, Teorija igara. Osnovne igre i primena, Drugo, dopunjeno izdanje, Beograd, Fakultet političkih nauka Univerziteta u Beogradu i Čigoja štampa, 2015, 7. See also Sluchin, op. cit., 1-2.

${ }^{6}$ For instance, I would like to mention the American composer and instrumentalist, John Zorn (b. 1953), who composed his game pieces starting from the 1970s; however, these are compositions based on collective improvisation, which often do not exist in traditional notation but only in the form of sound recordings, and the sound result is governed by precise verbal instructions. Cf: Tom Service, "A guide to John Zorn's music", https://www.theguardian.com/music/tomserviceblog/2012/may/21/contemporary-composers-guide-john-zorn (accessed on 13 December 2016). Zorn's best known piece of this type is Cobra for ensemble (1984).

7 DeLio, Thomas, “Structure and Strategy: Iannis Xenakis' Linaia-Agon”, Journal of New Music Research, 16, 1987, 143.

${ }^{8}$ Xenakis, Iannis, "Musiques formelles. Nouveaux principes formels de composition musicale", La Revue musicale, Double numéro spécial, $N^{\circ} 253$ et 254, Paris, Editions Richard Masse, 1963, https://iannis-xenakis.org/ (accessed on 4 May 2016). The chapter dedicated to stochastic music is called "Musique stochastique markovienne", 61-131. For the purpose of quotations I used the English language edition of the book: Iannis Xenakis, Formalized Music. Thought and Mathematics in Composition, Revised Edition, Additional material compiled and edited by Sharon Kanach, Harmonologia Series No. 6, Stuyvesant NY, Pendragon Press, 1992. 
case control is no longer in the hands of the conductors ${ }^{9}$ - it does not come as a surprise that this interesting piece is not frequently performed and that it falls in the category of lesser known compositions by Xenakis. Certain musicians - some of whom had had the experience of performing the piece Linaia-Agon - undertook the difficult duty of explaining the "rules of the game" of this composition. Besides the aforementioned analytical papers by the trombonist Benny Sluchin and composer Thomas DeLio, another interesting study was written by the trombonist J. Tyler Bentley. ${ }^{10}$

The title of the piece Linaia-Agon contains an adverb - "Linaia", derived from the name of Linos, the celebrated musician from the ancient Greek legends, ${ }^{11}$ thus revealing the programmatic nature of this composition (unlike Duel and Stratégie which do not have any such references). According to one of the legends, ${ }^{12}$ Linos challenged Apollo, the god of the arts, to a duel, thus putting himself at risk of being destroyed - and according to the story, that is exactly what happened. The narrative in the core of the piece serves as the impetus of the musical action. However, the composer does not limit himself to "retelling" the story literally, using musical means and instrumental "voices": on the contrary, he changes the outcome of the story by introducing the element of indeterminacy. The moral of the myth about Apollo and Linos is that a man should not challenge the gods because otherwise he will be punished. But in Xenakis's piece the challenge of Linos is not (pre)destined to failure - rather, the "mortal" has been given a fair chance to win the duel against the deity. It is precisely in this manner that Xenakis transforms the narrative into play: for, according to French writer and philosopher Roger Caillois, a game should be unpredictable,

\footnotetext{
${ }^{9}$ Both pieces for orchestra are scored for two groups of musicians with two conductors.

${ }^{10}$ Bentley, J. Tyler, "The Formal and Harmonic Structures of Linaia-Agon" http://jtylerbentley.com/files/FormalHarmonic.pdf (accessed on 17 August 2016).

11 "Linus (or Linos), according to some scholars, the son of the muse Calliope and brother of Orpheus, is considered the greatest musician ever to appear among mankind. He is the composer both of ballads in honor of Dionysus and the other ancient heroes and an epic of the creation. He is the inventor of rhythm and melody and the teacher of both Orpheus and Thamyris. According to legend, Apollo, who tolerated no rivals in music, killed Linus one day in a blind, jealous rage." Cf. DeLio, op. cit., 144.

${ }^{12}$ Xenakis told this legend in the radio programme called Double audition dedicated to contemporary music in 1973, retelling the origins of the piece Linaia-Agon as well. The host of the radio programme was Ivan de Tissot, and in the course of the programme the recording of the piece (made in 1972 in Metz) was broadcast. Together with Xenakis, the musicians who had made this recording took part in the programme, anaysing the piece. These were Georges Barboteu, French Horn, Camille Verdier, Trombone and Elie Renaud, Tuba. The transcript of the programme (in French language) is available at the end of Benny Sluchin's article, op. cit., 11-16.
} 
uncertain. Caillois defines play as a "free and voluntary activity", which is essentially a "separate occupation, carefully isolated from the rest of life" by way of being - supposedly - "carefree"; but, at the same time, it absorbs the player intensely, and comprehensively. The game takes place within its own limits of space and time, according to fixed rules and in a circumscribed way. The outcome should not be known in advance: a game allows for "error or surprise". ${ }^{13}$

Two out of the five segments of Linaia-Agon are based on controlled indeterminacy, and that is how Xenakis introduces the "surprise factor" into his composition, which nevertheless unravels according to strict rules - just like playing a game.

\section{What is the Name of the Game?}

A game is defined as a "set of all the rules which govern the course of the game and the players' behaviour". ${ }^{14}$ There are various classifications of games, most of them deriving from the field of mathematics. ${ }^{15}$ Even though Linaia-Agon could be analysed according to mathematical criteria (and then it would be non-cooperational, two player, infinite, zero-sum, asymmetrical, etc.), here I would like to draw attention to the categorisation elaborated by Roger Caillois ${ }^{16}$ which, to my knowledge, has not yet been applied to Xenakis' game pieces. Caillois divides all games into four categories or "rubrics, depending upon whether, in the games under consideration, the role of competition, chance, simulation, or vertigo is

${ }^{13}$ Caillois, Roger, "The Definition of Play and the Classification of Games", in Katie Salen and Eric Zimmerman, The Game Design Reader. A Rules of Play Anthology, Cambridge, MA \& London, The MIT Press, 2006, 125-126. In Serbian: Rože Kajoa, Igre i ljudi, Drugo izdanje, Beograd, Nolit, 1979, 32, 34-35.

${ }^{14}$ Mukić, Nataša, Teorija igara: Matematičke osnove mitova i paradoksa, unpublished master thesis, Novi Sad, University of Novi Sad, Faculty of Science and Mathematics, 2014, 6.

${ }^{15}$ For instance Nataša Mukić classifies all games into eight groups according to various criteria: 1) according to the players' interests - cooperational, non-cooperational and mixed-motive games; 2) according to the criteria of presence or absence of the element of chance games of hazard and strategic games; 3 ) according to the number of players - one player, two players or an arbitrary number of players; 4) according to the number of possible strategies - finite and infinite; 5) according to the information presented to the players - with complete information or with incomplete information; 6) according to the function of payment - zero sum and non-zero sum; 7) according to the way of presentation of the game - in normal form and in extensive form; and 8) according to the equality of chances for the participants - symmetrical and asymmetrical (antisymmetrical). Ibid. 7-8.

${ }^{16}$ Roger Caillois' typology of games was introduced in Serbian musicology by Zorica Premate in her book Dvanaest lakih komada, Beograd, Prosveta, 1997, in the chapter "Musica Ludens", notably 161-164. 
dominant. I call these agôn, alea, mimicry, and ilinx, respectively". ${ }^{17}$ Agon, ${ }^{18}$ to begin with, stands for competitive games such as various sports games (football, basketball, tennis, pool, chess); alea $^{19}$ designates games of chance (roulette, lottery and similar); mimicry is the "role play" or "pretend" (Cowboys and Indians, Doctors and Nurses); while ilinx relies on movements which are supposed to produce in the player feelings of instability, loss of balance, vertigo (a merry-goround, hopscotch, "Ring a Ring o' Roses").

Even though the title of the piece Linaia-Agon indicates that the game in question is a competitive one - and it is not a false assumption, at least not entirely - I would like to argue that the piece mixes together all game types defined by Caillois - notably agon and alea, but also mimicry and, in a certain way, ilinx as well. First of all, when speaking about games based on competition (agon), Caillois stresses the importance of the equality of the contestants: "(...) like combat in which the equality of chances is artificially created, in order that the adversaries should confront each other under ideal conditions". ${ }^{20}$ In Linaia-Agon both opponents are given a fair chance to win, unlike in the original story where the contest is clearly unfair. ${ }^{21}$ Alea, according to Caillois, reveals the "favor of destiny". 22 Perhaps it is not surprising to discover that the fourth segment of Linaia-Agon is called "Destiny Suspense" (Fr. "Suspens du Destin") - for here, the suspense results from alea-toric procedures used in the preceding two sections, as I am going to show later. Mimicry - disguising oneself, "wearing a mask, or playing a part" 23 - is revealed in this piece in the fact that the musicians "play the parts" of Apollo and Linos: the trombone portrays the human, while Apollo is represented, in alternation or simultaneously, by the French horn and tuba. The piece also encompasses two additional "roles": these are the "referee" - who keeps track of the unfolding of the duel and pronounces the winner - and the "accountant" - who assists the "referee" in writing down the points

${ }^{17}$ Caillois, "The Definition of Play....", 130.

${ }^{18}$ Literal meanings of the word agon (Gr. $\gamma \omega \dot{v}$ ) are: "combat, duel, battle, contest".

${ }^{19}$ Alea (Lat.) means "throw of the dice".

${ }^{20}$ Caillois, op. cit., 131.

${ }^{21}$ However, Thomas DeLio argues that Xenakis early in the work suggests that "Apollo" has some advantage over "Linos", because he is represented by two instruments and "Linos" by only one. Moreover, in terms of register those two instruments, the horn and the tuba, can, and often do, surround and completely envelope the trombone. Cf. De Lio, op. cit., 149. Later in his analysis DeLio demonstrates how Xenakis created structural advantages for "Apol10 " by placing particular values in the game matrices in the central, aleatoric segment of the piece, ibid. 155-156.

22 Caillois, op. cit., 133.

23 Ibid. 135. 
and calculating the score. ${ }^{24}$ In this respect I would argue that Linaia-Agon can also be considered as an example of instrumental theatre, even though Xenakis is not usually regarded as a representative of this important subgenre of European avant-garde music. ${ }^{25}$ Finally, the category of games called ilin $x^{26}$ can be related to this piece quite provisionally, having in mind the extreme difficulties that the musicians are faced with during the preparations and the actual performance of this composition: thus Linaia-Agon can be regarded as some sort of "vertiginous game" which pushes the psycho-physical abilities of the musicians to the limit.

I would like to stress the otherwise unaccented fact that in this piece Xenakis lucidly combined two opposite game types: the game of chance - alea (involving the element of chance) and the strategic game-agon (which as a rule does not involve the element of chance)! As observed by Caillois, "they both obey the same law - the creation for the players of conditions of pure equality denied them in real life. (...) Play, whether agôn or alea, is thus an attempt to substitute perfect situations for the normal confusion of contemporary life". ${ }^{27}$ Xenakis's playing with games resulted in his piece Linaia-Agon in an autochthonous and extremely complex music system, which represents an exciting challenge for interpretation.

\footnotetext{
${ }^{24}$ The role of the "accountant" is auxiliary and it can be omitted in the case when the "referee" is capable of following the course of the contest and writing down the scores on his own. ${ }^{25}$ The notion of instrumental theatre is commonly linked to the name of another representative of the post-WWII avant-garde, Maurizio Kagel (1931-2008). According to Håkon Thelin, Kagel "strived to rediscover what had been lost in Western classical music: the visual and kinetic nature of performance including communication and interaction with the audience, the physicality of music-making implying the erroneousness of a live performance, the bodily presence of the performers who are invited to a shared identification in the unique recreation of the work." Another important aspect of instrumental theatre observed by Thelin is its focus is on the visual and theatrical energy that lies implicitly in the performance itself, in the creation and bringing forth of single sounds and music on instruments, and in the communication and relationship between musicians and the audience. In other words, instrumental theatre is visualising the music. Cf. Håkon Thelin, "A new world of sounds - recent advancements in contemporary double bass techniques", Programme for Research Fellowships in the Arts in collaboration with the Norwegian Academy of Music, http://haakonthelin.com/multiphonics/ the-story-of-zab/part-1-the-story-of-zab/section-3-a-brief-retrospect-of-instrumental-theatre (accessed 12 December 2016). Many prominent avant-garde composers followed Kagel in the exploration of the bodily and visual aspects of the instrumental performance.

${ }^{26}$ Ilinx are games which are "based on the pursuit of vertigo and which consist of an attempt to momentarily destroy the stability of perception and inflict a kind of voluptuous panic upon an otherwise lucid mind". Cf. Caillois, op. cit., 138.

${ }^{27}$ Ibid., 135.
} 


\section{Playing with the narrative: bringing the legend of Linos and Apollo to life}

Thomas DeLio argues that

games were a central part of ancient Greek culture and were always intimately tied to mythology. Greek contests, then, constituted a physical acting out of the myth; the activities of the imagination brought, momentarily, to actual physical presence. In the spirit of the ancient Greeks, Xenakis uses the mathematical game to bring a mythical conflict into a momentary physical representation (albeit, an acoustical rather than athletic one). Thus, rather than merely dramatizing a myth, Xenakis' composition exemplifies the ancient Greek's use of games as a means of externalizing the conflicts and contests which constitute the very essence of the ancient myths. ${ }^{28}$

The piece Linaia-Agon consists of five distinct sections which "narrate" the mythical music duel between the man and the god. These sections are 1. "Linos Against Apollo" (Linos contre Apollon), 2. "Choice of Combats" (Choix des combats), 3. "Combats and Interludes" (Combats et interludes), 4. "Destiny Suspense" (Suspens du Destin), and 5. "Victory Chant and Requiem" (Chant de Victoire et Requiem). All sections of the piece are performed attacca, however, the form of the piece as heard in performance has three main formal sections: an introduction and conclusion that are fixed, unchangeable, and a middle section that is aleatoric in form. ${ }^{29}$

The first section of the score, serving as an introduction, contains "subtitles" written in several places above the staves: these are "Commencement" (bars 1-12), "Apollo" (bars 13-38), "Challenge by Linos" (bars 39-53), "Linos" (bars 54-72) and "Apollo accepts the challenge" (bars 73-99). The textures which will be used in the central part of the piece ("Combats and Interludes") are introduced in this first segment. ${ }^{30}$ As observed by DeLio, the "dramatic action of Part A is not simply an instance of tone painting. It also affords the composer an opportunity to introduce those sonic characteristics associated with the various strategies for each instrument in the forthcoming games, and identifies both the alignments and oppositions among the three performers as they now proceed to 'play' several two-person games. ${ }^{31}$ Xenakis explained the choice of instruments to represent both contestants in the following way: "I chose the trombone, which is a lot more agile than the two other instruments, to represent Linos. And then I chose (...) the extreme depth and sharpness of the sound for Apollo, because the voice of the God is solemn and piercing at the same time - and it is also in-be-

${ }^{28}$ DeLio, op. cit., 144-145.

${ }^{29}$ DeLio, op. cit., 148; Bentley, op. cit., 2-3.

${ }^{30} \mathrm{Cf}$. Sluchin, op. cit., 3. For a detailed analysis of the musical content of the piece, see DeLio, op. cit., 149-151.

${ }^{31}$ DeLio, op. cit., 152. 
tween the two - but it is also much bigger, like Homer put it: 'the big voice of the Gods in one stroke"'. 32

The following two sections, "Choice of Combats" and "Combats and Interludes", together form the middle part of the piece and these are the only aleatoric segments of the piece, varying in structure and in duration from one performance to another. Symbolically, they represent the "musical duel" with an unknown outcome. The second section, as its name says, serves to determine the sequence, durations and a number of repetitions of "combats" in the following section called "Combats and Interludes". This central segment consists of three subsections - three "combats", marked with letters of the Greek alphabet: $\alpha$, $\beta$ and $\gamma$. From time to time they can be separated by the interlude ("Inbetween the $\alpha, \beta, \gamma$ Combats"), which can be performed as a whole or just its segments, whichever the performers wish - as another aleatoric dimension of Linaia-Agon.

After the "combats", while the musicians are playing the fourth section "Destiny Suspense", the points are added and the winner of the duel is subsequently pronounced by the "referee". Finally, the musicians play the "Victory Chant and Requiem", glorifying the winner and mourning the looser.

The trio of musicians who took part in the performance and recording of the piece Linaia-Agon in 1972 pointed to the interesting reactions of the audience who, in their opinion, felt what was going on between the performers and realised the importance of the contest, even though it was not capable of deducing rationally the details of the musical organisation and the mathematical calculation of the winner. Moreover, the musicians testified to the "cheering" behaviour of the audience, who reacted when it was displeased with the decisions of the referee: ,[T] he trombone plays all the time because it is alone. The composer charged him with characteristic things to do and many tones to play. What it does make is a stronger impression on the audience than what the French horn or tuba do. And yet, in the end, the referee pronounces the Horn/tuba the winner. (...) The audience is not familiar with the rules and it wishes that the human, i.e. Linos, would have a better chance of winning". ${ }^{33}$

32 "J'ai choisi le trombone, qui est beaucoup plus agile que les autres instruments, pour représenter Linos. Et j'ai choisi (...) l'extrême grave et l'aigu pour Apollon, parce que la voix de Dieu est grave et aiguë en même temps — le médium aussi — mais elle est beaucoup plus large, comme le dit Homère : « la grande voix des Dieux d'un trait "”. Cf. Sluchin, op. cit., 11.

33 "[L]e trombone joue tout le temps, parce qu'il est seul. Le compositeur lui a donné des choses assez caractéristiques à faire avec beaucoup de notes à jouer. Ces choses ont un effet sur le public plus important que l'effet obtenu par le cor ou le tuba. Et à la fin, malgré cela, l'arbitre déclare le cor/tuba comme le vainqueur... Le public ne connaissant pas les règles du jeu, voulait que l'humain qui est Linos ait plus de chance." Cf. ibid. 15. 


\section{Playing with the Aleatorics: the game play}

In the third chapter of his book Formalized Music, entitled "Musical Strategy -Strategy, Linear Programming, and Musical Composition", Xenakis explains how he came up with the idea of creating the "heteronomous" musical discourse, which is based on the external conflict of two participants who perform a piece of music (for instance, two opposing orchestras or instrumentalists) unlike the traditional "autonomous" discourse, which is based on the "internal conflict" of the performer(s). ${ }^{34}$ In the heteronomous discourse, "[o]ne party's move would influence and condition that of the other. The sonic discourse would then be identified as a very strict, although often stochastic, succession of sets of acts of sonic opposition. These acts would derive from both the will of the two (or more) conductors ${ }^{35}$ as well as from the will of the composer, all in a higher dialectical harmony". ${ }^{36}$

In short, the piece Linaia-Agon, just like the other two Xenakis' "game pieces", uses the type of strategic game called "two-person zero-sum". This type of game relates to a competitive situation in which the gain of one player is equal to the loss of the other ${ }^{37}$ The participants in this game draw alternating "moves" by choosing one of the strategies ${ }^{38}$ at their disposal, which results in different amounts of gains or losses. In the score of Linaia-Agon Xenakis provides the matrices which determine the values of gains or losses for the participants in the duel, depending on the strategies chosen by each player. There are four such

${ }^{34}$ Xenakis describes the "internal conflict" as the "opposition between the sonic realization [of a piece of music] and the symbolic schema [i.e. the score, J.J.B.] which plots its course". Xenakis, op. cit., 110.

${ }^{35}$ As I have already mentioned, Xenakis explained his principles of aleatoric composition in Formalized Music using his own compositions Duel and Stratégie as examples, and they are both written for two orchestral groups with two conductors.

${ }^{36}$ Xenakis, op. cit., 111.

${ }^{37}$ Xenakis explains: "Let us imagine a competitive situation between two orchestras, each having one conductor. Each of the conductors directs sonic operations against the operations of the other. Each operation represents a move or a tactic and the encounter between two moves has a numerical and/or a qualitative value which benefits one and harms the other. This value is written in a grid or matrix at the intersection of the row corresponding to move $\mathrm{i}$ of conductor $\mathrm{A}$ and the column corresponding to move $\mathrm{j}$ of conductor $\mathrm{B}$. This is the partial score ij, representing the payment one conductor gives the other. This game, a duel, is defined as a two-person zero-sum game. The external conflict, or heteronomy, can take all sorts of forms, but can always be summarized by a matrix of payments $\mathrm{ij}$, conforming to the mathematical theory of games." Cf. ibid., 112.

${ }^{38}$ A strategy is the basic notion in the game theory and it is defined as a set of alternatives that a player has at his disposal when making a decision. $C f$. Mukić, op. cit., 6 . 
matrices in the piece, one in the section "The Choice of Combats" and one for each combat (" $\alpha ", " ~ " \beta "$ " and " $\gamma ")$. Each matrix lists the number of points awarded to a player for choosing one of the strategies. In the section "The Choice of Combats" players' strategies are marked with letters (" $\alpha$ ", " $\beta$ " and " $\gamma$ "); in the sections "Combat $\alpha$ " and "Combat $\beta$ " they are marked with specific symbols which the composer designed himself, and in the segment "Combat $\gamma$ " strategies are marked with the Roman numerals $I, I I$ and $I I I$. These so called "strategies" are actually certain types of musical textures which are to be played by the musicians - "Linos" and "Apollo" - in the given sections of the piece. Thus the duel is fought by using musical means as "weapons".

The "Choice of Combats" matrix consists of three strategies, while the matrices of the combats " $\alpha$ ", " $\beta$ " and " $\gamma$ " contain the fourth strategy - silence. For obvious reasons, this strategy is not written in the score, but it is marked in the corresponding matrices because not playing also brings points to the contestants (Chart 1).

\section{CHART 1 - MATRICES OF COMBATS IN LINALA-AGON}

Matrix "The Choice of Combats":

\begin{tabular}{|c|c|c|c|c|c|c|}
\hline \multicolumn{7}{|c|}{ APOLLO (tuba) vertical axe } \\
\hline \multirow{6}{*}{$\begin{array}{l}\text { LINOS } \\
\text { (trombone) } \\
\text { horizontal axe }\end{array}$} & $\begin{array}{l}\text { Strate- } \\
\text { gies: }\end{array}$ & A & $\beta$ & $\gamma$ & \multirow{6}{*}{$\begin{array}{l}4 / 15 \\
10 / 15 \\
1 / 15\end{array}$} & \multirow{4}{*}{$\begin{array}{l}0,26 \\
0,66 \\
0,06\end{array}$} \\
\hline & & -3 & -8 & 7 & & \\
\hline & B & 2 & 2 & -3 & & \\
\hline & $\Gamma$ & -8 & 12 & 2 & & \\
\hline & & $2 / 5$ & $1 / 5$ & $2 / 5$ & & \\
\hline & & 0,40 & 0,20 & 0,40 & & \\
\hline
\end{tabular}

Matrix "Combat $\alpha$ ":

\begin{tabular}{|c|c|c|c|c|c|c|}
\hline \multirow{7}{*}{$\begin{array}{l}\text { LINOS } \\
\text { (trombone) }\end{array}$} & \multicolumn{6}{|c|}{ APOLLO (tuba) } \\
\hline & \multirow{2}{*}{$\begin{array}{l}\text { Strategies:* } \\
\infty\end{array}$} & $\infty$ & .. & I & \multicolumn{2}{|c|}{ silence } \\
\hline & & -2 & 0 & 0 & 0 & 9 \\
\hline & 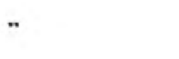 & 1 & 0 & -3 & -2 & 3 \\
\hline & I & 0 & -1 & 1 & -2 & 8 \\
\hline & silence & 0 & -1 & -2 & 1 & 7 \\
\hline & & 5 & 7 & 3 & 3 & $V=-5 / 9$ \\
\hline
\end{tabular}

\footnotetext{
* The symbols used here represent an approximation of the hand-drawn symbols used in the score.
} 
Matrix "Combat $\beta$ ":

APOLLO (French horn)

\begin{tabular}{|c|c|c|c|c|c|c|}
\hline \multirow{6}{*}{$\begin{array}{l}\text { LINOS } \\
\text { (trombone) }\end{array}$} & Strategies: & $\infty$ & $"$ & I & silence & \multirow{6}{*}{$\begin{array}{l}92 \\
78 \\
89 \\
76 \\
V=0,054\end{array}$} \\
\hline & \multirow{4}{*}{$\begin{array}{l}\infty \\
- \\
/ \\
\text { silence }\end{array}$} & 1 & -2 & -2 & 3 & \\
\hline & & 1 & -1 & 0 & -2 & \\
\hline & & 0 & 4 & -2 & -2 & \\
\hline & & -2 & -1 & 5 & 1 & \\
\hline & silence & 16 & 61 & 72 & 41 & \\
\hline
\end{tabular}

Matrix "Combat $\gamma$ ":

APOLLO (French horn and tuba)

\begin{tabular}{|c|c|c|c|c|c|c|}
\hline \multirow{6}{*}{$\begin{array}{l}\text { LINOS } \\
\text { (trombone) }\end{array}$} & Strategies: & I & II & III & silence & \multirow{2}{*}{109} \\
\hline & I & 2 & -6 & 0 & 1 & \\
\hline & II & -3 & -3 & -2 & 2 & 130 \\
\hline & \multirow{3}{*}{$\begin{array}{l}\text { III } \\
\text { silence }\end{array}$} & -5 & -1 & 3 & -4 & \multirow{2}{*}{$\begin{array}{l}11 \\
276\end{array}$} \\
\hline & & -3 & 0 & -3 & -5 & \\
\hline & & 13 & 23 & 68 & 91 & $\mathrm{~V}=$ \\
\hline
\end{tabular}

In strategic games there is an optimal strategy for each player; in "two-person zero-sum" games it is determined mathematically according to the so-called "minimax" theorem. ${ }^{39}$ Xenakis says that "there is an optimum way of playing for $A$, which, in the long run, guarantees him a minimum advantage or gain over $B$ whatever $B$ might do; and that conversely for $B$ there is an optimum way of playing, which guarantees that his disadvantage or loss under $A$ whatever $A$ might do will not exceed a certain maximum. $A$ 's minimum gain and $B$ 's maximum loss coincide in absolute value; this is called the game value". ${ }^{40}$ In the context of Linaia-Agon this basically means that "Linos" should be pursuing the positive value of the score while "Apollo" should try to obtain the negative value of the score in order to emerge victorious. Of course, this is the result of Xenakis's decision, i. e. of the choice of values that he put in the matrices of each combat. ${ }^{41}$

${ }^{39}$ Xenakis explains the minimax theorem in the following way: "the minimum score (maximin) corresponding to $X$ 's optimum strategy is always equal to the maximum score (minimax) corresponding to Y's optimum strategy", Xenakis, Formalized Music, 118. He illustrates this theory using his piece Duel as an example (ibid., 113-122), but its application is essentially the same as the one used in Linaia-Agon.

40 Ibid., 112

${ }^{41}$ Benny Sluchin demonstrates in his article that Xenakis revised Linaia-Agon on several occasions over the years after the piece was first printed, changing values in the matrices and 
The proportional chances for the choice of a certain strategy by "Linos" or "Apollo" are shown (as fractions) at the margins of the matrices (CHART 1). However, in practice, Xenakis allowed the possibility that the musicians/players would not have to choose the strategy which, in the composers' opinion, has the best chance of being chosen; moreover, the choices can be made intuitively, which makes for a totally unpredictable outcome of the contest. However, Bentley rightfully emphasizes the fact that "it is the proportional chances for each tactic [i. e. strategy, J.J.B] that reveal the statistical construct in the aleatoric form of Linaia-Agon" ${ }^{42}$ Sluchin also suggests the approach which "consists of adopting a strategic attitude by following the marginal proportions". 43

Since the "Choice of Combats" serves to determine the position, durations and repeats of the Combats " $\alpha$ ", " $\beta$ " and " $\gamma$ " in the third section of the piece, each strategy in this second segment is marked with the same Greek letter which will later correspond to the titles of the forthcoming "combats". At this point the referee should carefully note the sequence of "strategies" and their durations, ${ }^{44}$ because this will directly influence the outline of the "Combats" segment. This should not be a difficult task since in the "Choice of Combats" all strategies for both duellists consist of single notes (i. e. pitches), the durations of which are determined freely (Ex. 1a):

supplying additional explanations. The last revision by the composer took place sometime in 1982. Cf. Sluchin, op. cit., 4-6.

42 Bentley, op. cit., 4.

${ }^{43}$ Sluchin, op. cit., 2.

44 DeLio explains how the "Choice of Combats" game provides the duration of play for combats " $\alpha$ ", " $\beta$ " and " $\gamma$ ", each time they are played: these are derived from the relative frequency of the occurrence of each outcome in this game. For instance, if a certain strategy appears three times in the "Choice of Combats", and another one twice, their durations in the following segment will be made in the proportion of 3:2. It is up to the performers and the referee to determine the basic unit of time to which these proportions will be applied. DeLio also warns that the choice of order, frequency of occurrence and durations for games " $\alpha$ ", " $\beta$ " and " $\gamma$ "are all very important, since "each game is biased toward one side or the other. Thus, if, for example, one game is biased against Linus and it is determined that this game is to be played more often and over longer periods of time than either of the other games, then Linus will obviously be placed at a severe disadvantage and may have little hope of ultimate victory." Cf. DeLio, op. cit., 154. 
Example 1a: "Strategies" in the "Choice of Combats" section (Copyright 1972, Salabert)

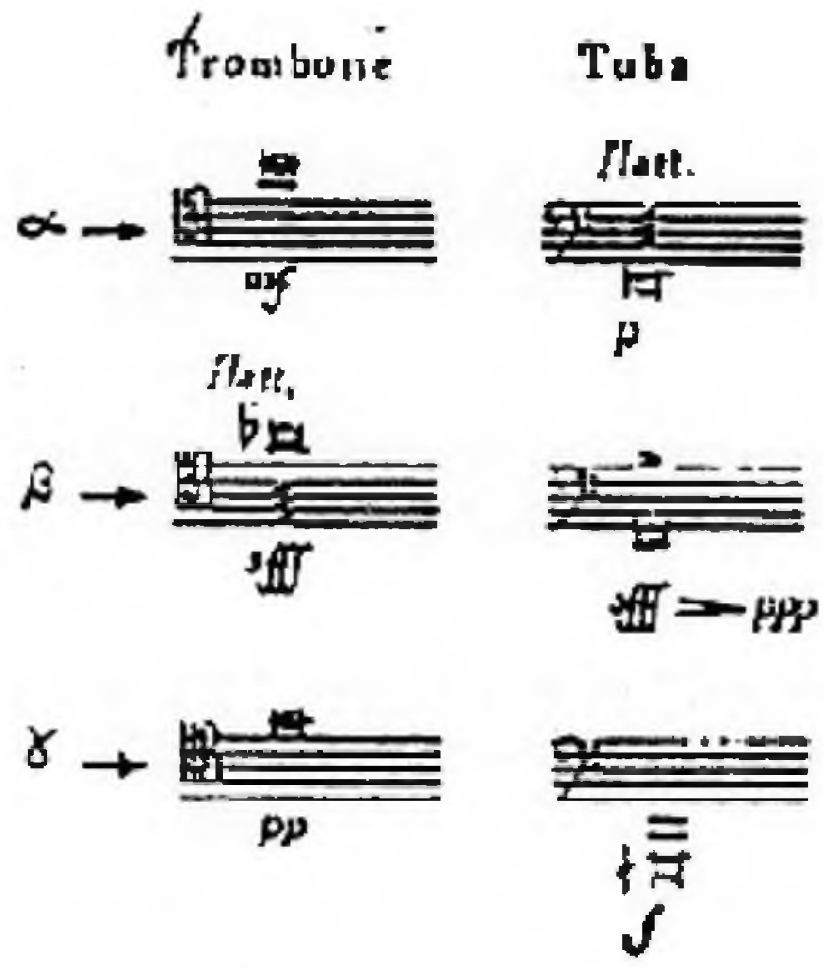

For example, the beginning of this segment took the following shape in the aforementioned recording made in Metz in 1972 (Ex. 1b):

Example 1b: Beginning of the "Choice of Combats" (1972) ${ }^{45}$

Trombone

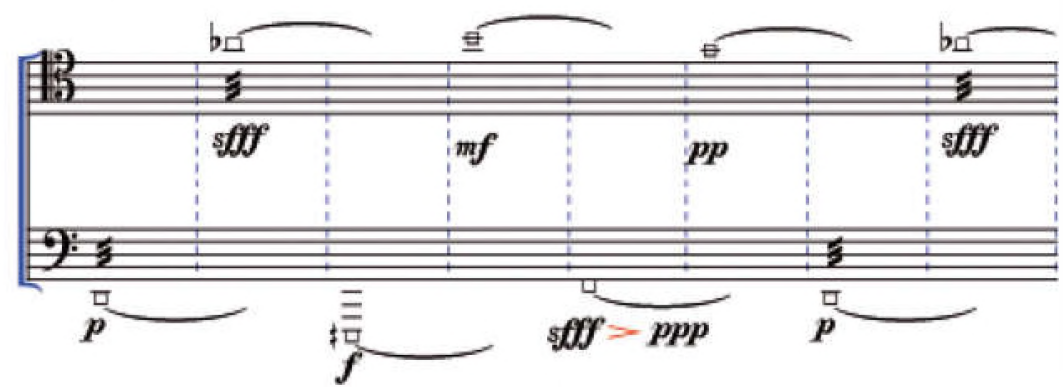

${ }^{45}$ Sluchin, op. cit., 13. 
Janković-Beguš, J., Playing the Game with Aleatorics and Narrativity: Linaia-Agon...

The sequencing of "strategies" as shown in the Example 1b was the following:

\begin{tabular}{|c|c|c|c|c|c|c|c|c|c|}
\hline Apollo & $\alpha$ & & $\gamma$ & & B & & $\alpha$ & & $\ldots$ \\
\hline Linos & & $\beta$ & & A & & $\gamma$ & & $\beta$ & \\
\hline
\end{tabular}

If I were to apply the "Choice of Combats" matrix to this sequence of strategies, I would see that "Apollo" began logically with the strategy " $\alpha$ " $(0,4 \%$ probability of choosing that particular strategy) which brought him $\mathbf{- 3}$ points; "Linos" responded by choosing - again logically - strategy " $\beta$ " $(0,66 \%$ probability) which brought him 2 points (let us not forget that "Apollo" is going for a negative score and "Linos" for a positive one!). Then "Apollo" went for the strategy " $\gamma$ " (-3 points, $0,4 \%$ probability), and "Linos" responded with his optimal move - strategy " $\alpha$ " (7 points); "Apollo" choose strategy " $\beta$ " ( -8 points), and so on. This brief analysis demonstrates that the musicians who took part in this recording were well aware of the values of each strategy and that they adopted the "mathematical" approach to their performance. ${ }^{46}$

Hypothetically, there is a possibility that one of the strategies would be completely omitted from the "Choice of Combats" - and that would consequently mean that the corresponding "combat" (" $\alpha$ ", " $\beta$ " or " $\gamma$ ") would not be performed at all in the central segment of the piece! In practice, however, the performers have usually decided to avoid such an outcome. ${ }^{47}$ Even though the total duration of the piece should be determined freely by the performers, Bentley shows in his analysis that the greater number of repeats of each combat brings the performers closer to the marginal probabilities calculated by Xenakis. ${ }^{48}$ However, in order to avoid excessively long durations (not forgetting the sheer physical demands of the performance on brass instruments), Bentley argues that it is sufficient to repeat each "combat" around four times in order to satisfy the "mathematical" and "artistic" demands of the piece. ${ }^{49}$

The musical content of the combats " $\alpha$ ", " $\beta$ " and " $\gamma$ " consists of certain textural motives, such as tremolos of varying pitch, glissandi, staccato structures, etc., all belonging to the expanded sound universe of the European postWWII avant-garde, and some of them highly typical of Xenakis. For instance,

\footnotetext{
46 It should be noted that the matrix of the "Choice of Combats" is the only one which is a "fair game" (game value $=0$ ), but it does not add to the overall numerical result - it only serves to organize the forthcoming game play. Cf. DeLio, op. cit., 153.

${ }^{47}$ Bentley, op. cit., 7.

${ }^{48}$ Ibid., 6-13.

49 Ibid., 16.
} 
in the "Combat $\alpha$ ", an interesting detail can be observed in the second strategy where the composer drew above the notes marks which resemble ascending and descending "hooks" (Ex. 2) in order to "notate" pizzicato glissando in the marked direction. ${ }^{50} \mathrm{It}$ is interesting to observe the controlled aleatoric quality of these textures, since they are carefully composed to sound indeterminate. It is also worth noting that in the Combat " $y$ ", where all three instruments perform at the same time, the two instruments portraying "Apollo" (French horn and tuba) must make a joint selection of "strategies" (I, II or III) to confront the trombone/"Linos", even though they do not play the same textural motives (Ex. 3).

There are other elements of aleatoric construction in the composition Linaia-Agon, some of them explicitly written in the score while the others are presumed. Bentley excellently sums up these "liberties", based on his analytical insight and practical experience in performing the piece, and these consider choices of durations, tempi, transpositions of pitches and of dynamic values, choices of the portions of musical textures to represent each strategy, etc. ${ }^{51}$

It is clear that Xenakis left considerable freedom of choice to the performers, but also that he gave a finite number of possibilities. Even though James Harley argues that "Linaia-Agon is certainly the most improvisatory of all Xenakis' scores, showing traces of Stockhausen's 'intuitive music', where the performers are guided both by the directions in the score as well as the choices of the other performers", ${ }^{52}$ I would like to stress the fact that Xenakis' piece has nothing to do with free improvisation - rather, it has to do with the choices of musical solutions which were elaborated and offered to the performers by the composer. In other words, Linaia-Agon is an example of controlled aleatoric music, which is, I believe, considerably different from Stockhausen's verbal scores of "intuitive music" such as Aus den sieben Tagen (1968). However, it is true that the structural organisation of Linaia-Agon poses an extremely difficult problem for each performer who must at all times be totally focused both on his/ her own musical expression and on the music played by the "opponent" which directly influences the unfolding of the piece, which is effectively "completed in performance". ${ }^{33}$

${ }^{50}$ For a more detailed account of the remarkable innovations that the post-war avant-garde brought into traditional music notation see: Tijana Popović-Mlađenović, Muzičko pismo, Beograd, CLIO, 1996. (second edition: Belgrade, Faculty of Music, 2015).

${ }^{51}$ Bentley, op. cit., 13-14.

52 Harley, James, Xenakis: His Life in Music, New York and London, Routledge, 2004, 26.

${ }^{53}$ Due to the scope of this text I will not tackle the complex problem circle of the "open work" as conceptualised by Umberto Eco in The Open Work, Translated by Anna Cancogni, Introduction by David Robey, Cambridge MA, Harvard University Press, 1989 (first pub- 
Janković-Beguš, J., Playing the Game with Aleatorics and Narrativity: Linaia-Agon...

\section{Example 2: Linaia-Agon, "Combat $a$ ”, bars 6-10}

(Copyright 1972, Salabert)

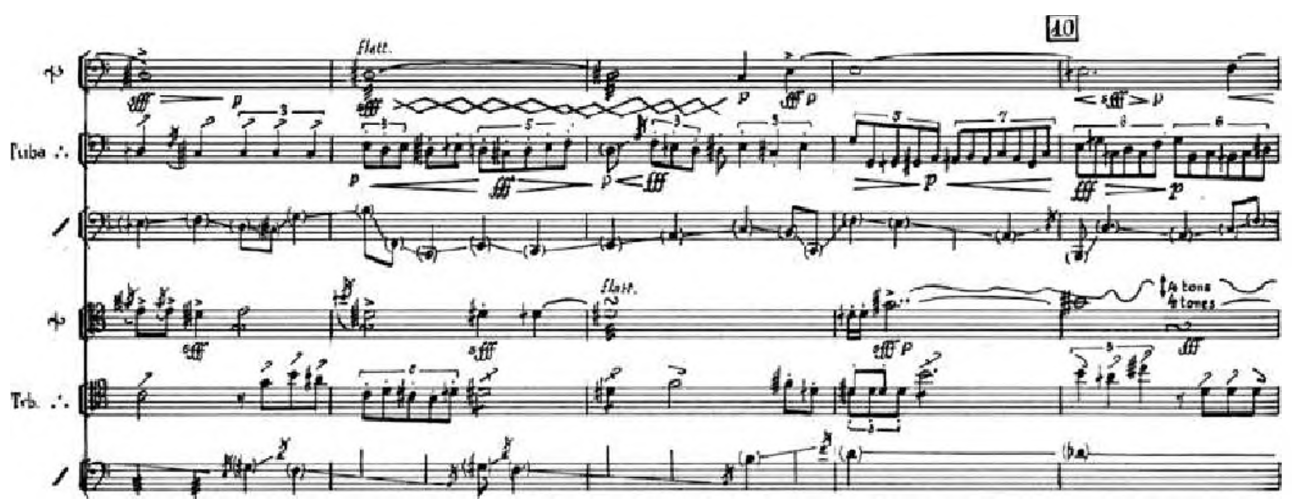

\section{Example 3: Linaia-Agon, "Combat $y$ ", bars 7-10}

(Copyright 1972, Salabert)

[10]

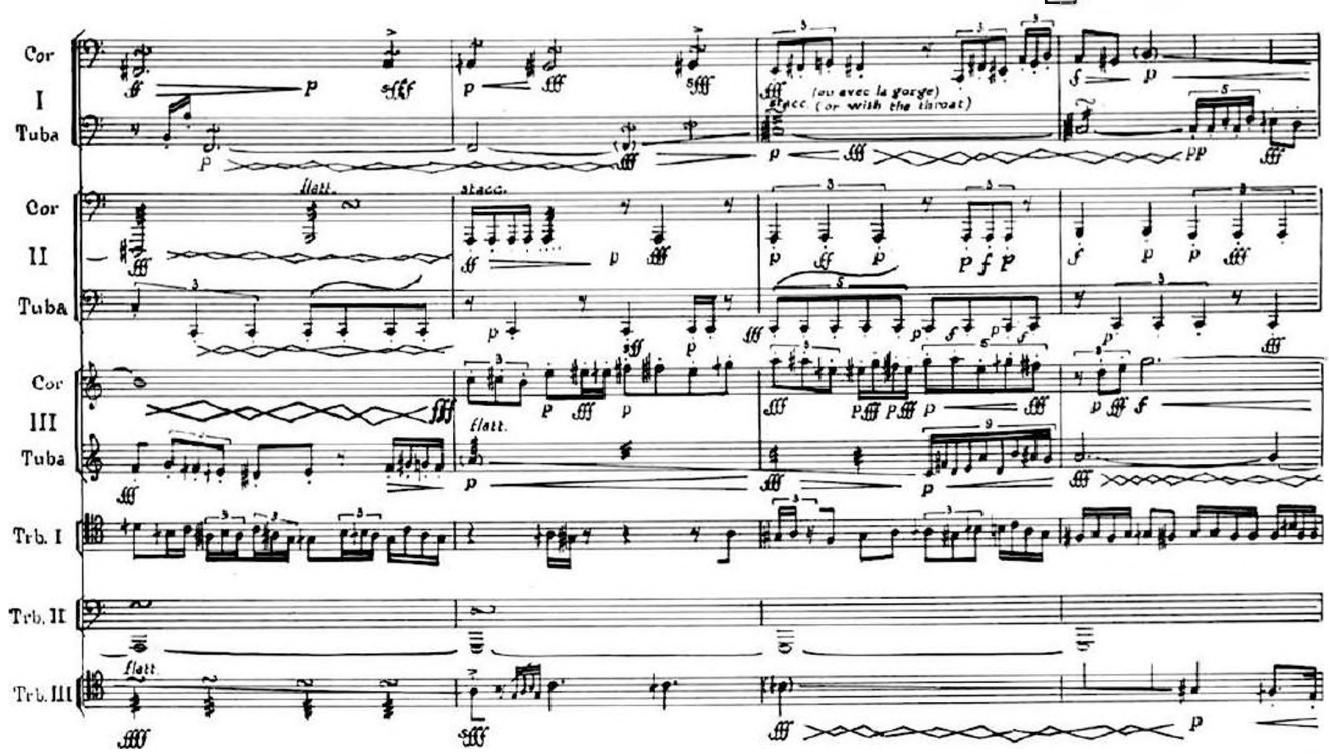

lished in Italian as Opera aperta, 1962), and which has been researched in relation to aleatoric music in a number of relevant studies. 
As observed by Benny Sluchin, who has also benefited from his experience as a performer of Linaia-Agon, ${ }^{54}$

[i]t is quite difficult to deliver a consistent musical discourse, listen to the choice of your opponent and watch the matrices for an optimal move. For these reasons, players tend to use a predetermined version of the piece: they determine a succession of combats, with their respective durations. Inside each combat, the strategies (playing modes) can also be predefined. Such a solution will result in a fluent musical dialogue, but will completely bypass the idea of a stochastic process in determining this central part of the piece. ${ }^{55}$

That is why Sluchin suggests that in order to ensure a spontaneous and lively performance the boxes with coloured cards should be used - one for each contestant, i. e. two boxes per "combat":

The referee draws one card from each box arbitrarily, and shows them to the adversaries. The musicians, react to the cards, and play the corresponding tactics, until the next draw. There is no pause between two successive tactics - the music should be continuous. The referee will take care of the succession of the combats and their duration, (he will indicate the passage to the interlude or to the following combat). The person who assists (the accountant) will note the points corresponding to each drawing. The public can thus follow the evolution of the score in real time, and the musicians can fully interpret the different tactics, in absolute continuity, and really combat the adversary. ${ }^{56}$

Even though Sluchin argues in the title of his article for a "performance based on the theory", I believe that this kind of solution would nevertheless point towards the intuitive (or at least accidental) approach to the performance, which would not result from the mathematical choice of optimal strategies but it would be musically more coherent and appealing. Another possibility would be to program a computer application which would facilitate the performance by displaying available strategies and ongoing results of the combats on monitors both to the performers and to the audience, thus allowing them to follow the course of the contest in real time. ${ }^{57}$

\footnotetext{
${ }^{54}$ In preparing Linaia-Agon for a concert in the Centre Georges Pompidou which took place in June 1982, with Péter Eötvös serving as a "referee", Sluchin had several working sessions with Xenakis. Cf. Sluchin, op. cit., 5.

55 Ibid., 7.

56 Ibid.

${ }^{57}$ For instance, in the recording of the piece which was released on DVD Iannis Xenakis : Le depassement de soi (Mode Records, mode 284) a computer interface was used which had been developed at IRCAM in cooperation with Benny Sluchin. For more details, see: http:// www.moderecords.com/catalog/284-xenakis.html (accessed 6 August 2016). However, this
} 
Janković-Beguš, J., Playing the Game with Aleatorics and Narrativity: Linaia-Agon...

\section{Conclusion: Outcome of the Game}

According to Caillois, "An outcome known in advance, with no possibility of error or surprise, clearly leading to an inescapable result, is incompatible with the nature of play. (...) The game consists of the need to find or continue at once a response which is free within the limits set by the rules. This latitude of the player, this margin accorded to his action is essential to the game and partly explains the pleasure which it excites". ${ }^{58}$ In this respect I would argue that the pleasure of performing a piece of aleatoric music such as Linaia-Agon lies in the unpredictable final result, in the excitement of "playing the game" and being completely absorbed by it.

Mathematics and music, which have been closely related ever since ancient times, are both expressions of the search for "symmetry, harmony and order in the supposedly chaotic world of endless possibilities". ${ }^{59}$ However, the attempts by numerous composers to bring together these two different "universes of the mind" have never guaranteed success and I believe that the results of such attempts - whether one takes into consideration the "Golden Ratio", serialization or any other mathematical procedure applied to music - have mostly depended on the composer's idea and its musical realisation. Xenakis himself shared this view, which he clearly stated in the second chapter of Formalized Music: speaking about the possibilities of the stochastic transformations of basic parameters of sonic entities and structures, he warned that the "sonic result thus obtained is not guaranteed a priori by calculation. Intuition and experience must always play their part in guiding, deciding, and testing". ${ }^{60}$ Xenakis' initial impetus for using stochastics was his presupposition that it "can lead to the creation of new sonic materials and to new forms", ${ }^{61}$ and he certainly did not think that mathematics was the beginning and the end of music.

interface still required that the musicians use the printed score (to read the musical textures corresponding to each "strategy") parallel with the monitors which displayed the unfolding of the combats. It would be simpler if a programme were designed which would display the strategies to each performer and at the same time "construct" the score as they go - displaying the appropriate segments of the score. Compare also Bentley, op. cit., 16, 18.

${ }^{58}$ Caillois, op. cit., 126.

${ }^{59}$ Madarász-Szilágyi, Rozália, Matematika i muzika, Novi Sad, Univerzitet u Novom Sadu, Prirodno-matematički fakultet, Departman za matematiku i informatiku, 2009, p. $1 \mathrm{http} / / /$ people.dmi.uns.ac.rs/ rozi/Rozi-licno/MATEMATIKA\%20I\%20MUZIKA.pdf (accessed 16 September 2016).

${ }^{60}$ Xenakis, op. cit., 81.

61 Ibid., 43. 
Certain authors such as Leslie and Hassanpour argue that Xenakis did not succeed in his attempt to create in his "game pieces" a framework for an activity that would be truly competitive even though he used "two-player zero-sum" games to model a predetermined musical interaction - because "the games that he used were of a size that made it impossible for the players to strategize". ${ }^{62}$ These authors also point to the already mentioned fact that the performers of the piece have sometimes planned their moves before the concert in order to convey more fluid interactions. In their opinion, the problem with Xenakis' game pieces is observed in that they "do not consider learning through repeated games, or any formalized approach to strategy". ${ }^{63}$ However, I believe that the musicians who performed Linaia-Agon would not entirely agree with the statement that it did not consider "learning through repeated games", i.e. that the performing experience was not accumulated with every interpretation, leading to the ever more assured and skilled interplay of the musicians.

This unique piece of music poses an additional problem for analysis, which has not yet been considered and which can hardly ever be resolved: in order to fully access the composer's success in creating a fair game contest, one would have to compile a "compendium" of scores based on performances of Linaia-Agon and to compare the success ratios of both players in terms of the mathematical results. Furthermore, data obtained in such a way would have to be compared with the musical results, i.e. to the analysis of the musical expression in performance - here again there are a limited number of recordings available for comparison. Only then, could one hope to get closer to unravelling the secret of a truly splendid performance of this playful piece of music.

Translated by the author

\section{References}

Bentley, J. Tyler, "The Formal and Harmonic Structures of Linaia-Agon", http://jtylerbentley. com/files/FormalHarmonic.pdf (accessed on 17 August 2016).

Boulez, Pierre, Relevés d'apprenti, Textes réunis et présentés par Paule Thévenin, Paris, Collection « Tel Quel » aux Éditions du Seuil, 1966.

${ }^{62}$ Cf. Leslie, Grace \& Hassanpour, Navid: "A Game Theoretical Model for Musical Interaction", p. 1, http://csdc-wiki.unistra.fr/cnsc/img_auth.php/8/83/Leslie_and_Hassanpour_A_game_theoretical_model_for_musical_interaction.pdf (accessed on 23 August 2016).

${ }^{63}$ Ibid. 
Janković-Beguš, J., Playing the Game with Aleatorics and Narrativity: Linaia-Agon...

Boulez, Pierre, “Alea”, prevela Daša Bradičić, in: Novi zvuk: izbor tekstova o suvremenoj glazbi, sastavio Petar Salem, Zagreb, Nakladni zavod Matice hrvatske, 1972.

Caillois, Roger, "The Definition of Play and the Classification of Games", in Katie Salen and Eric Zimmerman, The Game Design Reader. A Rules of Play Anthology, Cambridge, MA \& London, The MIT Press, 2006, 122-155.

DeLio, Thomas, "Structure and Strategy: Iannis Xenakis' Linaia-Agon", Journal of New Music Research, 16, 1987, 143-165.

Eco, Umberto, The Open Work, Translated by Anna Cancogni, Introduction by David Robey, Cambridge MA, Harvard University Press, 1989.

Feisst, Sabine, "Negotiating Freedom and Control in Composition. Improvisation and its Offshoots 1950 to 1980", in The Oxford Handbook of Critical Improvisation Studies, Vol. 2, Edited by George E. Lewis and Benjamin Piekut, New York, Oxford University Press, 2016.

Harley, James, Xenakis: His Life in Music, New York and London, Routledge, 2004.

Grace Leslie \& Navid Hassanpour: "A Game Theoretical Model for Musical Interaction", http://csdc-wiki.unistra.fr/cnsc/img_auth.php/8/83/Leslie_and_Hassanpour_A_game_ theoretical_model_for_musical_interaction.pdf (accessed on 23 August 2016).

Madarász-Szilágyi, Rozália, Matematika i muzika, Novi Sad, Univerzitet u Novom Sadu, Prirodno-matematički fakultet, Departman za matematiku i informatiku, 2009 http:// people.dmi.uns.ac.rs/ rozi/Rozi-licno/MATEMATIKA\%20I\%20MUZIKA.pdf (accessed on 16 September 2016).

Myerson, Roger B., Game Theory: Analysis of Conflict, Cambridge, MA \& London, Harvard University Press, 1991.

Mukić, Nataša, Teorija igara. Matematičke osnove mitova i paradoksa (neobjavljeni master rad), Novi Sad, Univerzitet u Novom Sadu, Prirodno-matematički fakultet, Departman za matematiku i informatiku, 2014.

Pavlović, Dušan, Teorija igara. Osnovne igre i primena [Game Theory: Basic Games and Applications], Drugo, dopunjeno izdanje, Beograd, Fakultet političkih nauka Univerziteta u Beogradu i Čigoja štampa, 2015.

Popović-Mlađenović, Tijana, Muzičko pismo, Beograd, CLIO, 1996. (second edition: Belgrade, Faculty of Music, 2015).

Premate, Zorica, Dvanaest lakih komada, Beograd, Prosveta, 1997.

Service, Tom, "A guide to John Zorn's music", https:/www.theguardian.com/music/tomserviceblog/2012/may/21/contemporary-composers-guide-john-zorn (accessed on 13 December 2016).

Sluchin, Benny, "Linaia-Agon: Towards an Interpretation Based on the Theory", https://www. iannis-xenakis.org/Articles/Sluchin.pdf (accessed on 13 May 2016).

Thelin, Håkon, “A new world of sounds - recent advancements in contemporary double bass techniques", Programme for Research Fellowships in the Arts in collaboration with the Norwegian Academy of Music, http://haakonthelin.com/multiphonics/the-story-ofzab/part-1-the-story-of-zab/section-3-a-brief-retrospect-of-instrumental-theatre (accessed on 12 December 2016).

Xenakis, Iannis, Linaia-Agon (published score), Salabert, 1972 (E.A.S 17.055). 
Xenakis, Iannis, Musiques formelles. Nouveaux principes formels de composition musicale, La Revue musicale, Double numéro spécial, N 253 et 254, Paris, Editions Richard Masse, 1963, https://iannis-xenakis.org/ (accessed on 4 May 2016). In English: Iannis Xenakis, Formalized Music. Thought and Mathematics in Composition, Revised Edition, Additional material compiled and edited by Sharon Kanach, Harmonologia Series No. 6, Stuyvesant NY, Pendragon Press, 1992.

http://www.moderecords.com/catalog/284-xenakis.html (accessed on 6 August 2016). 